\title{
Cara Pandang Barnabas si Anak Penghiburan
}

\author{
Ferry Susanto ${ }^{a, 1}$ \\ a Sekolah Tinggi Filsafat Driyarkara, Jakarta, Indonesia \\ 1 jhoseph21@yahoo.com
}

Keywords:

Barnabas;

Kisah Para Rasul;

Paulus;

kemuridan;

Gereja Perdana

\begin{abstract}
This paper deals with a narrative analysis on a figure, named Barnabas in the Book of Acts of The Apostle. The story of Barnabas in the Bible cannot be separated with Paul, the famous character in the Early Church, who is known as the Apostle of the nations. Transformation of Barnabas in Acts displays a role model for every Christians until today. Luke in Acts 9 tells the beginning of relationship between Barnabas and Saul, where Barnabas helped Saul from the series of rejections from the disciples of the Lord in Jerusalem. This relationship perfectly developed until they served hand in hand to spread the good news to the nations. As known, Barnabas and Saul have a serious conflict about Mark, the young man, the nephew of Barnabas. Eventually, this dynamic duo of the Early Church separated, where they took their own paths (Acts 15:39). Despite they have a disagreement, there is no hostility between them. From the story of Barnabas, we can learn how to solve so many differences in our missions as the disciples of Jesus.
\end{abstract}

\section{PENGANTAR}

Berbicara tentang spiritualitas dan karya penggembalaan Bapak Uskup Kardinal Ignatius Suharyo, tampaknya tidak bisa dilepaskan dari topik pembicaraan seputar Kitab Suci. Bukan saja beliau adalah seorang Profesor Kitab Suci, pengajar Kitab Suci yang sudah banyak makan asam garam, tetapi Kitab Suci secara nyata menjadi nafas hidup dan oase bagi pribadi dan pelayanannya.

Dalam beberapa kesempatan di tahun 2018-2019, misalnya: pada saat Bapak Uskup memberi masukan untuk Temu Pastores KAJ tahun 2018-2019 di Villa Via Re- nata, Cipanas-Bogor, dalam masukan beliau di hadapan para imam diosesan KAJ pada pertemuan UNIO di pertengahan 2018 di Wisma Samadi, Klender, juga dalam beberapa kali pertemuan Temu Pastores KAJ, Bapak Uskup Ignatius Suharyo sering kali mengulas dengan menarik dan sederhana dua tokoh yang sangat dikaguminya. Mereka adalah Paus Fransiskus dan Barnabas. Tampak sekali, kedua tokoh ini bukan hanya menjadi contoh dari figur-figur hebat yang harus dikagumi dan diteladani oleh para imam di Keuskupan Agung Jakarta, tetapi lebih dari itu, keteladanan kedua tokoh ini 
sangat mewarnai cura animarum, keputusan-keputusan serta sikapnya sendiri selaku gembala umat di tengah Keuskupan Agung Jakarta.

\section{LATAR BELAKANG}

Tulisan ini akan membahas kemunculan tokoh Barnabas dalam Kitab Suci dengan menggunakan metode naratif. Keunikan seorang karakter dalam Kitab Suci akan semakin terpancar ketika kita mencermati proses transformasinya dalam narasi Kitab Suci dan membandingkannya dengan karakter-karakter lain di dalam Kitab Suci, khususnya figur-figur yang berhubungan langsung dengan tokoh tersebut. Figur Barnabas dalam Kisah Para Rasul tidak bisa dipisahkan dari Saulus yang kemudian oleh Kisah Para Rasul disebut Paulus. ${ }^{1}$ Mereka berdua adalah dua soko guru jemaat yang sangat berpengaruh dalam sejarah perkembangan Gereja Perdana. Dinamika relasi dua pribadi hebat ini diawali dengan sangat indah, di mana Barnabas "menyelamatkan" Saulus yang waktu itu tidak dipercaya oleh rasul-rasul lain. Pembaca Kisah Para Rasul bisa membayangkan sekaligus bertanya-tanya, apa yang akan terjadi pada diri Saulus di awal pertobatannya sebagai orang pilihan Tuhan, bila ia tidak ditolong oleh Barnabas?

Pembaca Kitab Suci juga bisa bertanya mengapa dan bagaimana dalam perkembangan Gereja Perdana selanjutnya yang dikisahkan dalam Kisah Para Rasul, Barnabas seolah mundur ke belakang layar setelah dirinya berkonflik dengan Saulus. Sebaliknya, Paulus tampil semakin cemerlang sebagai Rasul segala bangsa. Pengalaman Barnabas sedikit mirip dengan pengalaman Yohanes Pembaptis yang mempersiapkan jalan bagi Tuhan (bdk. Yoh 1:19-30). Tetapi apakah Kisah Para Rasul hanya menampilkan figur
Barnabas sebagai pembuka jalan saja bagi Paulus? Sebesar apapun nama Paulus dalam perkembangan Gereja awal, tidak bisa mengaburkan begitu saja peran besar si Anak Penghiburan dalam sejarah Gereja.

Paulus dan Barnabas adalah rekan sekerja dan rekan seperjalanan dalam mewartakan kabar gembira Injil. Keduanya menerima perutusan yang sama dari Roh Kudus. ${ }^{2}$ Bahkan keduanya pernah mengalami konflik tajam dalam pelayanan mereka. Konflik besar biasanya menimbulkan perpecahan bahkan permusuhan. Tetapi hal itu tidak terjadi pada diri Barnabas dan Saulus. Rekonsiliasi yang terjadi dalam relasi dua orang ini sudah barang tentu menghindarkan Gereja dari sebuah perpecahan yang serius.

Melalui dinamika relasi Barnabas dan Paulus, Gereja Kristus bertumbuh dan menjadi dewasa dalam iman dan kasih Kristus berkat kesaksian iman dan value yang dimiliki oleh dynamic duo ini. ${ }^{3}$ Sebagai seorang tokoh yang besar jasanya atas hidup Saulus, tindakan Barnabas dalam berkonflik dengan orang yang pernah ditolongnya tentunya menjadi sebuah keteladanan besar bagi setiap orang kristiani bahkan sampai saat ini.

\section{METODE KARAKTERISASI DALAM NARASI KITAB SUCI}

Pendekatan narasi adalah salah satu pendekatan/metode membaca Kitab Suci yang dapat membantu pembaca Kitab Suci untuk menggali kekuatan karakter seorang tokoh yang diceritakan dalam Kitab Suci. Pendekatan narasi mengajak pembaca Kitab Suci untuk menikmati apa yang dibaca secara utuh (bukan sepotong-sepotong), mencermati dinamika perkembangan hidup seorang tokoh dengan teliti dan menangkap pesan yang mau disampaikan dalam firman Tuhan. 
Selain plot atau alur sebuah kisah, hal lain yang juga menarik untuk dikembangkan dalam pendekatan narasi adalah penokohan atau karakter. Biasanya pendekatan narasi berfokus pada seorang tokoh, mulai dari mengungkap keadaannya mula-mula, relasinya dengan tokoh-tokoh lain dalam cerita, bagaimana ia diberlakukan oleh orang lain atau pun sebaliknya. Penokohan dalam sebuah cerita, apalagi dalam Kitab Suci, bertujuan untuk mendidik umat beriman. Pembaca Kitab Suci diajak untuk belajar dari pergulatan iman dari para tokoh yang dinarasikan. Maka dari itu dalam narasi Kitab Suci biasanya dimunculkan konflik yang biasanya menjadi puncak ketegangan sebuah cerita. Di akhir narasi biasanya mengungkap bagaimana konflik itu diselesaikan di akhir cerita.

Alur dalam sebuah narasi selain menyampaikan rangkaian peristiwa demi peristiwa secara rapi dan teratur, ternyata juga bisa membawa pembaca untuk melihat sebuah transformasi dari seorang tokoh. Proses transformasi seorang tokoh bisa terlihat juga bila kita membandingkan dengan tokoh-tokoh lain yang juga diceritakan dalam Kitab Suci.

Biasanya dalam cerita Kitab Suci, perkembangan iman seorang tokoh ditampilkan secara bertahap, di mana ada perubahan atau perkembangan dalam diri tokoh tersebut dalam setiap tahapnya. Perubahan perlahan yang dialami oleh seorang tokoh dapat terlihat ketika kita mencermati secara teliti kemunculan tokoh itu di awal kisah, di tengah, sampai akhir. Perubahan akan tampak dalam statusnya, perkataannya, sikapnya, keadaannya, kedekatan dan kedalaman imannya dengan Yesus. Semakin sering dan panjang lebar seorang tokoh dimunculkan dan diceritakan dalam teks-teks Kitab Suci, semakin mudah pembaca melihat alur dan perkembangan yang utuh dari karakter yang sedang dianalisa.

Di awal tahun 1970, seorang ahli Kitab Suci yang bernama Raymond F. Collins menganalisa secara cermat tokoh-tokoh dalam Kitab Suci, khususnya murid-murid Yesus dan orang-orang terdekat Yesus dalam Injil Yohanes. ${ }^{4}$ Collins mencermati setiap kata, tindakan, relasi yang tercipta, baik relasi mereka dengan Yesus, Sang Guru, maupun relasi mereka dengan tokoh-tokoh lain yang juga diceritakan. Collins menemukan bahwa tokoh-tokoh yang diceritakan dalam Injil Yohanes memainan peran penting yang disebutnya dengan ungkapan "representative figures". Setiap tokoh mewakili salah satu aspek dari komunitas kristiani. Seperti potongan kecil sebuah puzzle, setiap tokoh membantu para pembaca untuk memperoleh gambaran yang lengkap tentang sikap iman yang dituntut oleh Yesus dari seorang murid dalam mengikuti Dia.

Analisa yang sama juga dilakukan oleh Alan Culpepper dalam pencermatannya mengenai tokoh-tokoh besar maupun kecil dalam Kitab Suci. ${ }^{5}$ Seorang tokoh bisa dikatakan sebagai tokoh besar bila kisah transformasinya dikembangkan secara utuh dalam sebuah cerita. Seorang penulis tokoh-tokoh dalam Perjanjian Baru biasanya memberikan sebuah informasi tentang keadaan awal tokoh besar tersebut, lalu pilihan-pilihan bebasnya, sampai konsekwensi dari pilihan hidupnya yang diterima oleh tokoh tersebut di bagian akhir kisahnya. Sebaliknya seorang figur bisa disebut sebagai tokoh kecil (minor character) bila hanya sebagian kecil saja dari kisah hidupnya yang diangkat oleh para penulis.

Melalui pendekatan karakterisasi yang sejalan dengan Collins, Culpepper menyimpulkan bahwa tokoh-tokoh dalam Injil ber- 
peran untuk menggambarkan salah satu sisi dari hidup Yesus yang harus dipahami oleh para pembaca. ${ }^{6}$ Dalam kisah tokoh-tokoh itu juga terdapat beberapa tindakan dan konsekwensi yang mereka alami ketika berhadapan dengan pribadi Yesus. Setiap tokoh dalam Injil Yohanes digambarkan memberikan reaksi pribadi mereka terhadap Yesus yang digambarkan sebagai tokoh utama dalam Injil Yohanes. Reaksi yang tepat dari seorang tokoh terhadap figur Yesus sangat menentukan nasib dan keselamatan yang mereka peroleh di kemudian hari. Maka dari itu, melalui pengalaman jatuh bangun tokoh-tokoh di sekitar Yesus, para pembaca juga dimampukan untuk memberikan jawaban yang tepat terhadap undangan kasih Allah dalam diri Yesus Kristus.

Selain menggali kemampuan dan teknik yang digunakan oleh penulis (the author) dalam menceritakan pengalaman orang beriman dalam Kitab Suci, pendekatan narasi juga memberi tempat bagi para pembacanya (the reader oriented). Daya transformasi yang dialami oleh tokoh-tokoh Kitab Suci tidak hanya berhenti pada tokoh-tokoh itu saja, tetapi diharapkan juga dapat menyentuh hidup para pembacanya. Ada suara Allah, rencana dan campur tangan Allah yang bekerja secara tersembunyi di balik tokoh-tokoh yang diceritakan dalam Kitab Suci. Diharapkan para pembaca Kitab Suci dapat berpartisipasi dalam arus transformasi itu. Para pembaca diajak untuk mengenali dan mengalami proses transformasinya sendiri bersama Tuhan dengan mengikuti arahan Firman Tuhan dan menemukan hidup mereka menjadi lebih baik dari pada sebelumnya sebagai orang beriman.

Apa yang sudah dikembangkan oleh Collins dan Culpepper seperti yang disinggung di atas, kini akan kita menerapkan analisa yang sama untuk melihat bagaimana Lukas, pengarang Kisah Para Rasul, mengembangkan karakter Barnabas dalam bukunya yang kedua. Wajah Barnabas yang ditampilkan dalam Kisah Para Rasul adalah wajah Gereja Perdana, yang menjadi warisan suci dan teladan luar biasa bagi para pembaca Kitab Suci sampai saat ini.

\section{MENGGALI KARAKTER POSITIF BARNABAS}

\section{Barnabas: Bukan Nama Asli Namun Lebih Sering Digunakan}

Kemunculan nama Barnabas dalam Kisah Para Rasul cukuplah unik karena ia lebih dikenal dengan nama julukan yang diberikan kepada dirinya dari pada nama aslinya sendiri. Barnabas adalah nama julukan atau panggilan, sedangkan nama aslinya adalah Yusuf. Yang memberikan nama baru kepadanya itu bukanlah orang sembarangan, tetapi kelompok para rasul yang mempunyai otoritas di tengah jemaat Kristiani waktu itu. Mungkin alasan itulah yang membuat nama Yusuf (nama asli Barnabas) tidak banyak bergaung di telinga pembaca Kitab Suci. Nama Yusuf tersebut hanya disebut satu kali dalam Kis 4:36, di mana dikatakan:

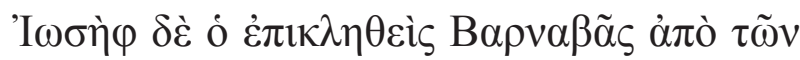

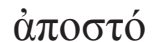

Yusuf, yang disebut Barnabas oleh rasul-rasul

Kisah Yusuf yang disebut Barnabas dapat membantu kita untuk mencermati penggunaan nama dan panggilan dalam kasus lain dalam Perjanjian Baru. Apakah nama julukan yang diberikan oleh pihak yang memiliki otoritas akan mengganti nama asli seorang tokoh. Hal itu tidak berlaku untuk pribadi-pribadi lain yang juga mendapatkan nama julukan dari orang-orang yang memi- 
liki otoritas dalam komunitas kristiani. Kita bisa membandingkan dengan tokoh-tokoh lain yang diberi nama sebutan dari pribadi yang mempunyai otoritas lebih dari dirinya.

Penginjil menceritakan Yesus memberi nama panggilan khusus kepada $3 \mathrm{mu}-$ rid-Nya. Simon diberi nama oleh Yesus dengan sebutan Petrus, yang artinya batu karang. Sementara Yakobus anak Zebedeus dan Yohanes saudara Yakobus diberi nama Boanerges, yang berarti anak-anak guruh

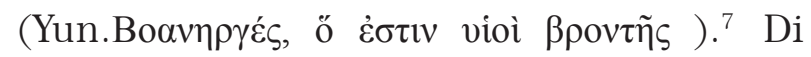
samping ada juga Rasul lain yang mempunyai nama julukan yaitu Tomas, yang disebut juga Didimus. Bukan sebuah kebetulan bila di Yoh 21:2, akhir Injil Yohanes, nama-nama yang disebutkan di atas disebut secara bersama-sama dalam peristiwa penampakan Yesus. ${ }^{8}$

Beberapa kali nama Didimus, julukan bagi Tomas, disebut secara eksplisit dalam teks Kitab Suci. Ada 3 kutipan dalam Injil Yohanes, ketika penginjil mempresentasikan
Tomas, secara eksplisit penginjil memberi informasi tambahan tentang nama julukan untuk Tomas (bdk. Yoh 11:16; 20:24; 21:2). Hanya Injil Yohanes yang menyebut nama julukan itu bagi Tomas, sementara Injil Sinoptik tidak sama sekali. Injil Yohanes juga tidak pernah menjelaskan arti dari nama Didimus $(\Delta i \delta v \mu o \varsigma)$ yang berasal dari kata Yunani

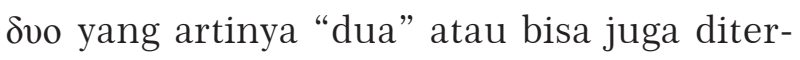
jemahkan secara harfiah dengan kata "si kembar”. Dari mana Tomas mendapat julukan itu dan apakah Tomas itu kembar atau memiliki kemiripan dengan orang tertentu, tidak pernah dijelaskan dalam Injil.

Injil dan Kisah Para Rasul lebih banyak menyebut nama Tomas (9x) tanpa menyebut atau memberi informasi nama panggilannya. ${ }^{9}$ Dari sini kita bisa melihat Kitab Suci mencatat nama Tomas lebih sering dipakai dari pada nama julukannya. Julukan Didimus bahkan tidak pernah dipakai atau disebut tanpa disandingkan dengan nama Tomas.

\begin{tabular}{|c|c|}
\hline Yoh 11:6; $21: 2$ & Yoh 20:24 \\
\hline 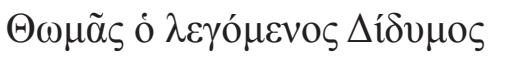 & 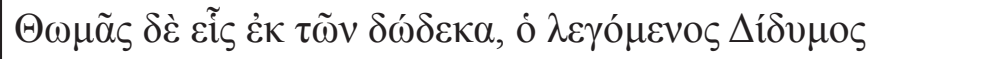 \\
\hline Tomas, yang disebut Didimus & $\begin{array}{l}\text { Tomas, seorang dari kedua belas murid itu, yang disebut } \\
\text { Didimus }\end{array}$ \\
\hline
\end{tabular}

Murid Tuhan lainnya, yaitu Simon, diberi nama oleh Yesus dengan nama baru, yaitu Petrus, yang artinya batu karang. Tetapi dalam beberapa teks Kitab Suci, kedua nama itu disandingkan sebagai satu kesatuan menjadi Simon Petrus. Pembaca dengan mudah mengetahui bahwa Simon adalah nama asli, sementara Petrus adalah sebuah nama julukan. Petrus sebagai nama asli tidak hilang begitu saja.

Dari 188 kali kemunculan nama Petrus dalam Perjanjian Baru, 19 di antaranya muncul bersanding dengan nama aslinya, menjadi "Simon Petrus". Terkadang para penginjil menggabungkan dua nama itu begitu saja. ${ }^{10}$ Namun ada kalanya penginjil memberi keterangan seperti: "Simon

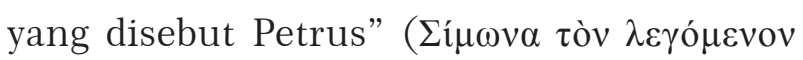

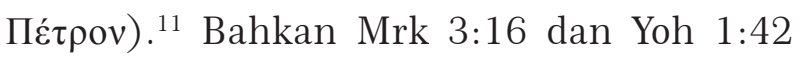
secara eksplisit menegaskan bahwa nama Petrus adalah panggilan Yesus kepada Simon. Setelah itu dalam beberapa kali kesempatan para murid lainnya, para penginjil dan juga jemaat perdana juga ikut memang- 
gil Petrus dengan sebutan Simon atau Simon Petrus. ${ }^{12}$ Kita juga bisa mencermati bahwa ketika Kisah Para Rasul menyebut nama-nama rasul Tuhan yang menanti-nanti Roh Kudus, penulis tidak dipakai nama Simon untuk Petrus. ${ }^{13}$ Dalam bagian ini nama Simon yang digunakan untuk murid lain, Si- mon orang Zelot. Nama Simon, yang merujuk pada Petrus, tidak pernah berdiri sendiri di dalam Kisah Para Rasul. Lukas pun hanya menggunakan gabungan dua nama itu hanya satu kali di Luk 5:8. Sebutan Simon Petrus paling banyak digunakan oleh Injil Yohanes. ${ }^{14}$

\begin{tabular}{|c|c|}
\hline Mrk 3:16 & Yoh 1:42 \\
\hline 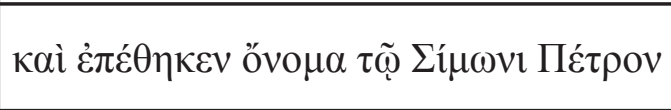 & 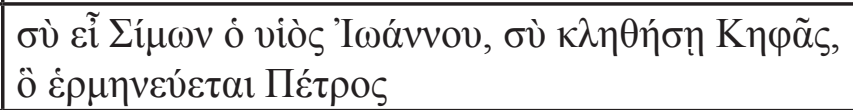 \\
\hline Simon yang diberiNya nama Petrus & $\begin{array}{l}\text { Engkau Simon, anak Yohanes, engkau akan dina- } \\
\text { makan Kefas, yang artinya Petrus }\end{array}$ \\
\hline
\end{tabular}

Ada beberapa alasan mengapa para penginjil dan Kisah Para Rasul lebih banyak menyebut gabungan nama Simon Petrus adalah adanya nama Simon yang lain dalam kelompok dua belas murid Yesus yang disebut dalam Injil, yaitu Simon orang Zelot. ${ }^{15}$ Selain itu Injil dan Kisah Para Rasul juga menceritakan tokoh Simon lainnya, yaitu Simon si kusta (Mat 26:6// Mrk 14:3), Simon dari Kirene (Mat 27:32//Mrk 15:21// Luk 23:26), Simon Iskariot ayah dari Yudas, murid yang mengkhianati Yesus (Yoh 6:71; 13:2, 26), Simon seorang penyihir yang bertobat menjadi kristen (Kis 8:9), Simon seorang penyamak kulit yang rumahnya pernah ditinggali oleh Petrus (Kis 9:43; 10:6, 17).

Ada banyak tokoh bernama Simon pada waktu itu yang bisa membingungkan para pembaca Kitab Suci. Dengan menggunakan gabungan nama Simon Petrus, para pembaca bisa terbantu, bahwa di antara banyak nama Simon yang disebut dalam Kitab Suci, Simon Petruslah yang lebih memainkan peran cukup sentral di kalangan murid Yesus sendiri, di kalangan komunitas kristiani, termasuk juga ketika Injil-Injil dan Kisah Para Rasul diceritakan dan ditulis. Dari penjelasan tentang nama asli dan julukan kita bisa menyimpulkan bahwa nama julukan tidak pernah menghilangkan nama asli seorang tokoh, minimal kedua nama itu dipakai bersama-sama. Hal tersebut tidak berlaku pada kasus seorang tokoh yang bernama asli Yusuf, yang disebut dengan panggilan Barnabas.

Dalam Kitab Suci Perjanjian Baru, nama Barnabas (B $\alpha \rho \alpha \beta \beta \varsigma)$ muncul sebanyak 37 kali, di mana 32 di antaranya nama ini banyak disebut dalam Kisah Para Rasul. Sementara sisanya, nama ini hanya muncul di 1 Kor 9:6; Gal 2:1, 9,13, Kol 4:10. Nama Barnabas tidak pernah disebut dalam Injil Sinoptik maupun Injil Yohanes. Dari data itu pembaca Kitab Suci bisa menyimpulkan bahwa Barnabas adalah salah satu jemaat Gereja Perdana di Yerusalem. Kisah Rasul 4:34-36 menjelaskan arti dari nama Barnabas, yaitu anak penghiburan (viòs $\pi \alpha \rho \alpha \kappa \lambda \eta ́ \sigma \varepsilon \omega s$, Ing. the son of encouragement). Nama Barnabas didapat dari panggilan para rasul kepada tokoh laki-laki saleh yang bernama Yusuf dari Siprus ini. Dari data kasar yang disebutkan di atas, secara umum kita bisa melihat betapa pentingnya figur Barnabas dalam perkembangan Gereja Perdana.

Dalam Kis 4:36 dikatakan nama asli dari Barnabas adalah Yusuf (ףסוי, dari akar kata Ibrani, פסי, berarti "menambahkan"). Arti 
nama Yusuf secara ekspisit dikatakan dalam Kitab Kejadian, ketika Rahel, istri dari Yakub, menyadari bahwa dirinya mengandung setelah penantian yang cukup lama, kemudian ia menamai anak laki-laki yang dilahirkannya itu dengan nama Yusuf. Dengan nama itu Rahel berharap mudah-mudahan TUHAN menambah seorang anak laki-laki lagi baginya (bdk. Kej 30:24). Selain Yusuf anak Yakub, dalam Kitab Suci ada lagi 2 nama Yusuf lainnya yang juga digambarkan cukup panjang lebar, yaitu: Yusuf suami Maria $^{16}$ dan Yusuf dari Arimatea ${ }^{17}$.

Bukan sebuah kebetulan bahwa tiga tokoh yang bernama Yusuf yang disinggung di atas digambarkan sangat positif sebagai pribadi-pribadi beriman dalam Kitab Suci. Bukan kebetulan juga, tokoh-tokoh itu juga mengalami proses transformasi yang cukup panjang sampai mereka berubah menjadi karakter yang mengagumkan. Mereka dibentuk oleh pengalaman hidup mereka, ada kalanya mereka jatuh dan terpuruk. Satu hal yang terlihat sama dalam pengalaman mereka masing-masing adalah mereka tidak menyerah atau tidak berhenti dalam berproses pembentukan iman mereka.

\section{Barnabas: Karakter Positif Sejak Awal}

Di awal kemunculannya, Kisah Para Rasul hanya sedikit memberi informasi tentang latar belakang Barnabas dan kepribadiannya. Di Kis 4:36 hanya disebut nama julukan dan artinya, sukunya dan dari daerah mana ia berasal. Dikatakan Barnabas adalah keturunan Lewi (keluarga imam di Israel), dari daerah Siprus, sebuah wilayah yang terletak di bagian Timur Laut Tengah (sebelah Selatan Turki). Surat Paulus kepada jemaat di Kolose memberi keterangan bahwa Barnabas adalah paman dari Markus, seorang tokoh muda yang kelak akan menjadi sumber perselisihan antara Barnabas dan Paulus di kemudian hari (bdk. Kol 4:10).

Kemunculan pertama Barnabas yang dicatat dalam Kisah Para rasul berada dalam konteks ketika Lukas menceritakan cara hidup Jemaat Perdana di Kis 4:32-37. Dikisahkan orang yang telah percaya pada Kristus, di bawah bimbingan para rasul hidup sehati dan sejiwa. Mereka menjadikan harta milik pribadi mereka menjadi milik bersama (ay. 32-33). Meski demikian mereka semua hidup dalam kelimpahan. Ayat 34-35 mencatat beberapa praktek kesalehan dan keutamaan yang dilakukan oleh jemaat perdana.

Kisah Rasul 4:36-37 dan 5:1-2 memberikan keterangan bahwa beberapa orang yang disebut namanya (subyek) melakukan seperti yang dilakukan oleh banyak orang yang telah percaya itu. Hal itu sangat didukung dari pengulangan kosa kata yang digunakan dalam ay.34b-35b. Ada 3 ungkapan yang selalu muncul dalam tiap bagian yaitu: "menjual", "membawa" dan "meletakkan di depan kaki para rasul”.

\begin{tabular}{|c|c|c|}
\hline Gereja Perdana (ay. 34b-35b) & Barnabas (ay. 36-37) & Ananias dan Safira 5:1-2 \\
\hline 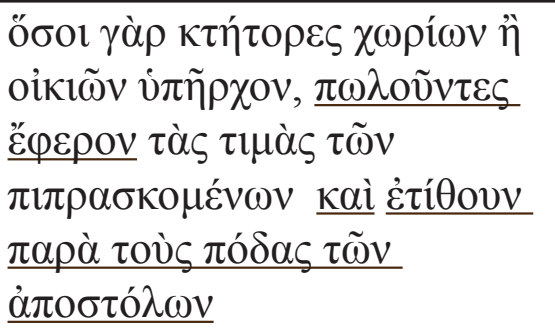 & 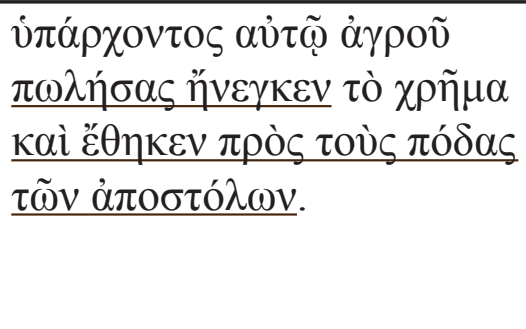 & 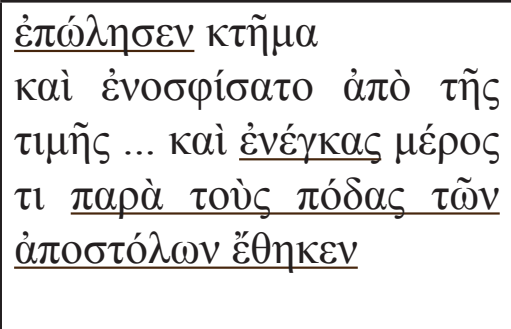 \\
\hline
\end{tabular}


semua orang yang mempunyai tanah atau rumah, menjual kepunyaannya itu, dan hasil penjualan itu mereka bawa dan mereka letakkan di depan kaki rasul-rasul.
(Barnabas) menjual ladang, miliknya, lalu membawa uangnya itu dan meletakkannya di depan kaki rasul-rasul.

(Ananias dan Safira) men-
jual sebidang tanah.... ia
menahan sebagian dari hasil
penjualan itu dan sebagian
lain dibawa dan diletakkan
di depan kaki rasul-rasul.

(Ananias dan Safira) menjual sebidang tanah.... ia menahan sebagian dari hasil penjualan itu dan sebagian di depan kaki rasul-rasul.
Dari perbandingan di atas tampak sekali penulis Kisah Para Rasul mencoba memberi penekanan sekaligus perbandingan yang sangat jelas antara Barnabas dengan tokoh-tokoh lain dalam cerita ini. Tokoh yang bernama Yusuf, yang dipanggil Barnabas oleh para rasul, adalah sebuah tokoh yang mengafirmasi hal yang sedang diceritakan. Tanpa keraguan bahwa si Anak Penghiburan ini adalah bagian dari "semua orang" (jemaat) yang diceritakan dalam ay. 34b-35b. Sebaliknya, setelah itu, tokoh Barnabas akan dibandingkan dengan sepasang suami istri, yang bernama Ananias dan Safira, yang diceritakan dalam bagian selanjutnya (Kis 5:1-11).

Meski suami istri ini juga telah menjual sebidang tanah mereka tetapi mereka hanya memberikan sebagian dari hasil penjualan itu kepada para rasul, sedangkan sebagian lagi disimpan untuk diri mereka sendiri. Setelah perbuatan mereka diketahui oleh Petrus, Ananias meninggal. Kata-kata Petrus kepada Ananias di Kis 5:4 menegaskan bahwa semua persembahan itu adalah suka rela sifatnya. Kesalahan Ananias adalah dia punya rencana jahat dengan mendustai Allah dan manusia. Kesalahan mereka diperburuk oleh Safira, istrinya di Kis 5:8. Safira berbohong untuk menutupi kesalahannya, sehingga ia juga mengalami nasib naas yang sama seperti suaminya. ${ }^{18}$

Perbandingan antara Barnabas dengan pasangan suami istri Ananias dan Safira kiranya mempertegas keluruhan karakter yang dimiliki oleh Barnabas, meski di Kisah
Rasul 4 pengarang belum menceritakannya secara eksplisit. Hal itu baru kita temukan di kisah-kisah selanjutnya. Kisah Rasul 11:24, Lukas menegaskan Barnabas sebagai pribadi yang baik, penuh dengan Roh Kudus dan iman. Bukan itu saja, bahkan Kis 13:1 menggelompokkan Barnabas sebagai salah satu dari kelompok nabi dan pengajar, bersama Saulus, Simeon yang disebut Niger, Lukius orang Kirene, dan Menahem yang diasuh bersama dengan raja wilayah Herodes.

Dari penjelasan di atas kita bisa menyimpulkan bahwa Kisah Para Rasul menampilkan Barnabas sebagai pribadi yang sangat positif. Dia konsisten dengan karakternya yang baik. Dia semakin berperan dalam komunitas kristiani. Dengan kata lain, benihbenih kebaikan dan keluhuran budi yang dimiliki oleh Barnabas, bertumbuh, berkembang dan berbuah dalam Gereja, yang tidak lain adalah komunitas murid-murid Tuhan.

\section{Barnabas: Relasi Awalnya dengan Saulus}

Kemunculan kedua Barnabas dalam Kitab Para Rasul bisa kita lihat dalam konteks pertobatan Saulus di Kis 9:1-31. Bagi Lukas, pertobatan Paulus adalah salah satu kisah yang paling penting dalam Kitabnya sekaligus menjadi tonggak penting dalam perkembangan kisah yang diceritakan dalam Kisah Para Rasul. Maka tidak heran, oleh Lukas, kisah pertobatan ini diceritakan sampai tiga kali di Kis 9:1-31; 22:4-16 dan 26:12-18. Fakta teks ini menantang beberapa ahli Kitab Suci untuk mengulasnya dengan cermat. ${ }^{19}$ 
Sejak kisah pertobatan Saulus di Kis 9:131, dari 32 kali kemunculan nama Barnabas dalam Kisah Para Rasul, ternyata nama ini hampir selalu bersanding dengan tokoh besar lainnya dalam sejarah Gereja Perdana yaitu Saulus. Sejak perjumpaannya dengan Saulus di Kis 9:27 seolah Barnabas jarang sekali disebut sendirian lagi, tetapi selalu bersama-sama dengan Saulus. ${ }^{20}$

Bila dibandingkan dengan Barnabas, Saulus tentu lebih dikenal sebagai nama besar dalam Gereja Perdana. Ia mempunyai kharisma luar biasa sebagai soko guru jemaat. Tetapi tidak banyak yang tahu bahwa dalam menjalani pelayanannya, Saulus pernah bersitegang bahkan berkonflik dengan sesama pelayan Firman lainnya seperti Barnabas bahkan Petrus. Karena kebersamaan Barnabas dan Saulus dalam Kisah Para Rasul, maka menggali karakter Saulus akan sangat membantu kita melihat lebih dalam karakter Barnabas si Anak Pengharapan.

Dalam salah satu usahanya mengejar orang-orang Kristen, Saulus melihat penampakan Tuhan Yesus di Damsyik atau Damaskus (Kis 9:3-9; Gal 1:17). ${ }^{21}$ Peristiwa itu menjadi titik balik yang sangat penting dalam hidupnya, dari orang yang sebelumnya mengancam dan membunuh murid-murid Tuhan, kini bertransformasi menjadi orang pilihan Tuhan untuk mewartakan nama Tuhan kepada bangsa-bangsa lain (bdk. Kis 9:15). Joseph Fitzmyer mengatakan peristiwa pertobatan Saulus dalam Kisah Rasul bab 9 ini bukan saja penting untuk hidup Saulus, tetapi juga faktor yang sangat penting bagi Kisah Para Rasul sendiri, sebab di sinilah gagasan penyebaran Injil kepada segala bangsa dimulai dalam kitab ini. ${ }^{22}$

Tuhan menyembuhkan Saulus melalui penumpangan tangan seorang tokoh lain bernama Ananias. Tuhan mengutus Ana- nias untuk pergi ke rumah seseorang yang bernama Yudas, seorang dari Tarsus, untuk bertemu dengan Saulus di sana. ${ }^{23}$ Kesulitan murid-murid Tuhan untuk menerima Saulus sebetulnya sudah mulai terlihat dari reaksi Ananias ketika ia menerima tugas dari Tuhan di Kis 9:13-14. Ini adalah penolakan pertama yang diterima oleh Saulus. Dengan tegas Ananias mengatakan bahwa Saulus adalah orang jahat dan motivasinya untuk datang ke Yerusalem tidak lain adalah untuk menangkap para pengikut Kristus. Tetapi setelah menerima penjelasan dari Tuhan, Ananias merubah pandangannya terhadap Saulus.

Perkataan Tuhan kepada Ananias dalam

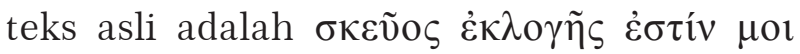
ỡ $\tau \varsigma$, dia adalah alat / bejana pilihan bagi$\mathrm{Ku}$ (Ing. he is for me a vessel of election). Paulus adalah alat pilihan untuk memberitakan nama Tuhan. ${ }^{24}$ Ketika ia menumpangkan tangan, Ananias menyapa Saulus dengan sebutan "Saudara Saulus" (Yun. $\Sigma \alpha$ ov̀ $\lambda \dot{\alpha} \delta \varepsilon \lambda \varphi \dot{\varepsilon}) .{ }^{25}$ Pertobatan awal Saulus ditandai bukan saja oleh kesembuhannya sehingga ia bisa melihat lagi, tetapi segera setelah itu ia minta diri dibaptis di Damsyik, tempat di mana ia tinggal bersama murid-murid Tuhan lainnya untuk beberapa waktu (Kis 9:18-19b; Kis 22:12-16). Di sini Saulus mampu melewati rintangan pertamanya.

Di Damsyik, Saulus mulai mewartakan Yesus sebagai Anak Allah. Kisah Rasul menceritakan reaksi penolakan kedua terhadap pertobatan Saulus. Kali ini keberatan muncul dari orang-orang yang mendengarkan pewartaannya. Seperti Ananias, mereka juga mempertanyakan dan mengungkit lagi masa lalu Saulus yang gelap dan motivasinya datang ke Damsyik, yang tidak lain adalah untuk mengejar para murid Tuhan. Dari 
keberatan orang-orang di Damsyik disebut juga kata "nama", seperti yang dikatakan Tuhan sebelumnya bahwa "nama" itulah yang membuat Saulus menderita. ${ }^{26}$ Kisah Para Rasul tidak menceritakan bagaimana resolusi terhadap keberatan orang-orang ini, plot langsung melompat pada informasi bahwa Saulus semakin berpengaruh, membingungkan orang-orang Yahudi dan juga membuktikan identitas Yesus sebagai Mesias (ay. 22). Untuk kedua kalinya Saulus bisa lolos dari rintangan, dan langsung diikuti oleh penolakan selanjutnya.

Penolakan ketiga terhadap Saulus kali ini datang dari kelompok orang Yahudi sendiri di Damsyik, bahkan mereka berusaha untuk membunuh Saulus. Sebuah ironi terjadi di sini, seorang yang dahulu suka membunuh pengikut Tuhan, sekarang mau dibunuh dengan alasan yang sama. Tetapi murid-murid Tuhan menyelamatkan Saulus dengan memasukkannya ke dalam keranjang lalu menurunkannya dari tembok kota (ay. 22). ${ }^{27}$ Penolakan dari kalangan Yahudi menegaskan status Saulus bahwa mulai saat itu ia berseberangan dengan mereka setelah sebelumnya Saulus ada di pihak mereka dengan memusuhi orang-orang kristen.

Dari sini kita bisa melihat bahwa 3 pengalaman penolakan yang dialami oleh Saulus seolah mempersiapkan pembaca untuk memasuki penolakan berikutnya yang merupakan penolakan paling vital, di mana Saulus juga akan ditolak oleh murid-murid Tuhan di Yerusalem. ${ }^{28}$ Pada saat itu Yerusalem adalah pusat kekristenan. Maka penolakan komunitas kristiani di kota ini akan sangat berdampak ke kota-kota lainnya.

Dikatakan ketika Saulus di Yerusalem, ia mencoba menggabungkan diri kepada murid-murid. Reaksi yang diterima oleh Saulus adalah mereka takut kepadanya, alasannya adalah mereka tidak percaya bahwa Saulus adalah murid Tuhan. Ketika banyak orang menolak Saulus karena masa lalunya yang buruk, diceritakan Barnabas menerima dan percaya pada Saulus. Dengan kata lain, Barnabas juga percaya bahwa Tuhan telah memilih Saulus menjadi muridNya, termasuk juga pertobatan yang dialami Saulus.

Bisa dibayangkan posisi Saulus saat itu menjadi sangatlah tidak mudah. Di kalangan orang Yahudi sendiri (kelompoknya yang lama), dia ditolak bahkan mau dilenyapkan. Sekarang di antara jemaat kristen (kelompoknya yang baru), ia juga tidak diakui dan tidak dipercaya. Sudah dapat dipastikan hal ini menjadi pil pahit buat Saulus, apalagi hal itu justru terjadi di awal pertobatannya. ${ }^{29}$

\section{Barnabas: Memberi Kesaksian Positif Tentang Saulus}

Di balik penolakan dan ketidakpercayaan banyak orang terhadap Saulus, yang dilakukan oleh Barnabas tidak hanya menerima dan percaya pada cerita Saulus saja. Apa yang dilakukan oleh Barnabas terhadap Saulus sangatlah cocok dengan arti dari nama julukan yang diberikan para rasul kepadanya, yaitu: “anak penghiburan”. Barnabas menjadi figur pembawa pengharapan di tengah ketakutan yang sedang dialami oleh jemaat Kristiani di Yerusalem saat itu. Barnabas telah menjadi jembatan dengan membawa Saulus kepada rasul-rasul di Yerusalem.

Strategi yang dilakukan oleh Barnabas ini sangatlah bijaksana sebab ketika terjadi keresahan di tengah jemaat, Barnabas justru membawa Saulus kepada para pemangku jemaat, yaitu para rasul di Yerusalem, yang mempunyai otoritas tertinggi untuk mengambil keputusan soal status Saulus. ${ }^{30}$ Bahkan Barnabas tidak membiarkan Saulus yang berbicara sendiri di depan para ra- 
sul, tetapi Barnabas sendiri yang bercerita untuk meyakinan para rasul. ${ }^{31}$ Barnabas memberi kesaksian atas karya Tuhan yang dialami oleh Saulus. Yang diceritakan oleh Barnabas adalah pengalaman Saulus ketika bertemu dengan Tuhan. Tampak sekali Barnabas memberi laporan yang lengkap tentang sepak terjang Saulus setelah pertobatannya.

Sebagai orang beriman, Barnabas mempunyai cara pandang yang unik dalam melihat segala sesuatu. Ketika banyak orang berfokus pada masa lalu dan kesalahan Saulus, tetapi Barnabas melihat Saulus secara positif. Hal itu terlihat dari cerita yang disampaikannya kepada para rasul Tuhan. Semua yang dialami dan dilakukan oleh Saulus di Kis 9:19-25 diringkas oleh Barnabas di Kis 9:27-30. Bahkan kalau kita cermati, Barnabas memberi kesaksian dan informasi yang lebih lengkap, seperti: soal jawab antara Saulus dan orang-orang Yahudi pada ay.22 ternyata mereka menggunakan bahasa Yunani (ay. 29). Demikian juga Barnabas menambahkan bahwa jemaat di Damsyik yang menyelamatkan Saulus dari orang Yahudi (ay.24-25), setelah itu Saulus dibawa ke Kaisarea lalu ke Tarsus (ay. 30).

Dari penceritaan Barnabas tentang Saulus di hadapan para rasul, pembaca Kitab Suci diajak untuk semakin mengenal Barnabas. Barnabas bukan hanya orang baik yang rela menjual ladangnya lalu memberikan hasil penjualan untuk banyak orang. Barnabas bukan hanya sekedar umat kristen yang saleh dalam Gereja perdana. Tetapi jauh dari pada itu, Barnabas adalah seorang yang memiliki pandangan positif. Ia mencoba mengenal pribadi orang lain (Paulus) secara utuh meski orang tersebut memiliki masa lalu yang kelam sekalipun. Ia memiliki hati yang luhur hingga mampu melihat lebih luas dimensi kehidupan orang lain juga pada karya Allah dalam perjalanan Gereja.

\section{Barnabas: Berhasil dalam Perutusan}

Setelah Kis 9:32-11:18 plot panjang lebar menceritakan karya pelayanan Petrus dan Kornelius, Kis 11:19 kembali bercerita tentang Banabas. Dikisahkan situasi jemaat semakin merana. Hukuman mati kepada Stefanus mendorong umat Tuhan terserak di beberapa daerah sampai ke Fenisia, Siprus dan Antiokhia. ${ }^{32}$ Kis 11:19 memberikan garis batas yang jelas bahwa sampai saat itu pewartaan Injil hanya diberikan kepada orang Yahudi saja.

Kisah Rasul 11:20 membuka babak baru terhadap pewartaan Injil, di mana diceritakan bahwa beberapa orang (orang Siprus dan orang Kirene) yang tiba di Antiokhia, juga mewartakan Injil, bahwa Yesus adalah Tuhan. ${ }^{33}$ Berkat pertolongan Tuhan, banyak orang menjadi percaya berkat pewartaan mereka itu. Situasi baru ini membuat jemaat di Yerusalem mengutus Barnabas untuk pergi ke Antiokhia. ${ }^{34}$ Dari sini kita bisa melihat bahwa Barnabas tidak dikirim ke Siprus, daerah asalnya.

Setiba di Antiokhia Barnabas bersuka cita karena melihat karya Tuhan yang telah terjadi di sana. Barnabas memberi nasihat kepada jemaat untuk tetap setia kepada Tuhan. Kis 11:23 memberi sedikit informasi bahwa salah satu kunci dari keberhasilan penyebaran Injil di Antiokhia adalah karena kepribadian Barnabas. Menarik ay. 24 diawali dengan kata "karena" (Yun, ö $\tau$. Ing. "for") lalu diikuti dengan kualitas pribadi Barnabas.

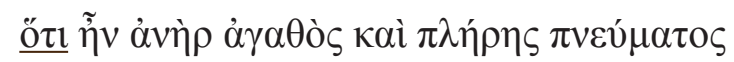

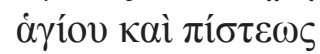

"karena (bahwa) orang baik penuh dengan Roh Kudus dan iman" 
Keberhasilan Barnabas bahkan dicatat di ayat ini: "sejumlah jemaat dibawa kepa-

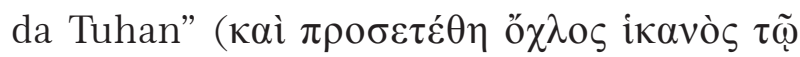
кupí(). Bisa dikatakan Barnabas berhasil dalam perutusannya di Antiokhia. Ia menjadi salah satu perintis awal dari perkembangan jemaat kristiani di Antiokhia, salah satu daerah di Syria, dan berperan penting dalam masa penjajahan Romawi. ${ }^{35}$

Suka cita dan tanggapan positif jemaat di Antiokhia membuat Barnabas pergi ke Tarsus. Kisah Rasul menuliskan dengan jelas, bahwa alasan Barnabas pergi ke Tarsus adalah untuk mencari Saulus (Kis 11:25). Setelah bertemu, Barnabas mengajak Saulus ke Antiokhia untuk membantu pelayanan di sana. Kedua orang ini bahu membahu mengembangkan jemaat di sana selama kurang lebih satu tahun. Keberhasilan dua utusan ini dikatakan dalam Kis 11:26. Teks ini memberi kesaksian yang menjadi tonggak penting jemaat Kristiani sampai sekarang, bahwa:

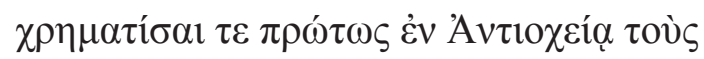

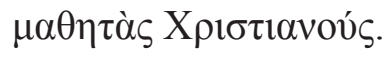

\section{Untuk pertama kalinya di Antiokhialah mu-} rid-murid itu disebut Kristen ${ }^{36}$

Kepercayaan jemaat di Antiokhia kepada Barnabas dan Saulus diceritakan dari bagaimana mereka berdua dipercaya untuk membawa uang dan bantuan yang dikumpulkan di sana untuk membantu saudara-saudara di Yudea (Kis 11:30). Setelah umat mendengar nubuat Agabus, seorang nabi yang datang dari Yerusalem. Agabus menubuatkan akan terjadi kelaparan besar di jaman Klaudius (41-54 M) ${ }^{37}$ Para murid di Antiokhia berinisatif mengumpulkan sumbangan untuk orang-orang di Yudea. Sumbangan itu diberikan kepada penatuapenatua di sana melalui perantaraan Barnabas dan Saulus.
Kita bisa memperhatikan teks di sini dan beberapa teks setelahnya, di mana dari sisi urutan, Barnabas disebut terlebih dahulu,

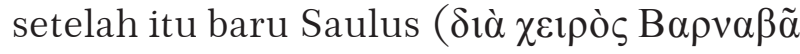

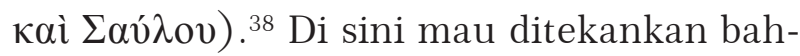
wa di awal posisi Barnabas lebih tinggi daripada Saulus. ${ }^{39}$ Satu hal yang menarik tentang ide ini adalah sebuah keberatan yang datang dari Gerd Lüdemann dalam bukunya Paul Apostle to the Gentiles, Studies in Chronology. Lüdemann berpendapat bahwa sebelum Paulus bergabung dengan Barnabas di Antiokhia, ia sudah memulai misinya sendiri di Tarsus. Demikianpun, ketika Paulus ke Yerusalem, statusnya bukanlah bawahan dari Barnabas, minimal dari sudut pandang Paulus sendiri, terlihat dari suratnya kepada jemaat di Galatia (bdk. Gal 2:12). ${ }^{40}$

Terhadap keberatan Lüdemann di atas kita bisa menanggai bahwa bagi umat Antiokhia, sebagaimana diceritakan dalam Kisah Rasul bab 11, Barnabas tentu lebih dikenal terlebih dahulu dibandingkan Paulus yang datang kemudian. Maka tidak heran bisa penulis Kisah Para Rasul menulis nama Barnabas di urutan pertama sebelum Saulus. ${ }^{41}$

Setelah berhasil menjalankan tugas pewartaan di Antiokhia, Kis 12:25 menceritakan bahwa Barnabas dan Saulus kembali ke Yerusalem. Mereka juga membawa orang muda yang bernama Yohanes yang disebut juga Markus, yang akan bertugas untuk membantu mereka. ${ }^{42}$ Dikatakan juga di Antiokhia sudah dilayani oleh sejumlah nabi dan pengajar selain Barnabas dan Saulus (Kis 13:1). Di Antiokhia beberapa umat yang sedang beribadah dan berpuasa mendapat pesan dari Roh Kudus untuk mengkhususkan Barnabas dan Saulus, untuk menjalani tugas yang sudah diperuntukkan kepada mereka (Kis 13:3). ${ }^{43}$ 
Menarik untuk disimak adalah nama-nama nabi dan pengajar yang disebut dalam Kis 13:1 di mana dalam daftar itu nama Barnabas ada dalam urutan pertama, sementara Saulus disebut paling akhir setelah Simeon yang disebut Niger, Lukius orang Kirene, dan Menahem. Kis 13:4 adalah bagian terakhir Barnabas disebut lebih dulu sebelum Saulus, sebab mulai Kis 13:42, posisi sudah terbalik.

Di paruh kedua Kisah Rasul bab 13 (ay. 9), terjadi perubahan penyebutan nama Saulus. Setelah sebelumnya penulis Kisah Rasul menyebut nama "Saulus", mulai Kis 13:9 dan seterusnya nama Saulus berubah menjadi Paulus. Hal itu terjadi ketika Kisah Rasul menceritakan perjalanan Barnabas dan Saulus, lagi-lagi diutus oleh Roh Kudus, berangkat ke Siprus dan mengelilingi seluruh pulau sampai ke Pafos. Di sana mereka berjumpa dengan seorang Gubernur yang bernama Sergius Paulus yang digoda untuk meninggalkan imannya oleh seorang penyihir bernama Baryesus (dalam bahasa Yunani namanya adalah Elimas). ${ }^{44}$ Paulus mengusir roh jahat dalam diri tukang sihir itu dan tukang sihir itu menjadi buta.

Sejak hal yang luar biasa itu terjadi, spotlight dari Kisah Para Rasul seolah bergeser dari Barnabas ke Paulus. Kis 13:13 dan seterusnya menceritakan perjalanan Paulus dan kawan-kawannya ke beberapa daerah. Di sini terjadi sebuah peristiwa yang akan dipermasalahkan oleh Paulus kemudian, yaitu Markus, keponakan Barnabas, meninggalkan mereka untuk kembali ke Yerusalem. ${ }^{45}$ Paulus memberikan kotbah panjang tentang serajah keselamatan Allah yang berpuncak pada Yesus Kristus, PuteraNya kepada orang-orang di Pisidia (lih Kis 13:16-49). Kotbah ini menjadi sebuah pembelaan iman murid-murid Tuhan dan menjadi tonggak penting dari pewartaan Injil kepada seluruh dunia. ${ }^{46}$ Tetapi kalau kita cermati, ada sebuah perubahan penting terjadi di dalam teks. Selain nama Saulus tidak lagi dipakai, tetapi juga mulai dari Kis 13:51 urutan nama menjadi Paulus dan Barnabas

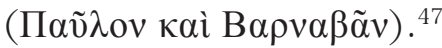

Selain menceritakan keberhasilan Paulus dan Barnabas, Kisah Rasul juga menuturkan penolakan yang mereka alami, misalnya di Kis 13:50. Perempuan-perempuan terkemua di Antiokhia dihasut oleh orang-orang Yahudi yang membuat Paulus dan Barnabas pergi dari Antiokhia. Mereka pun pergi ke Ikonium, di mana pewartaan mereka dipercaya oleh orang-orang Yunani, tetapi tetap ditolak oleh orang-orang Yahudi di sana. Perjalanan kedua murid Tuhan ini dilanjutkan di Listra di mana mereka diagung-agungkan setelah Paulus menyembuhkan seorang yang lemah kakinya dan lumpuh sejak lahir (Kis 14:8).

Karena mukjizat penyembuhan itu mereka didewakan, Barnabas mereka sebut Zeus dan Paulus disebut Hermes. Tidak hanya itu saja, mereka juga menerima aneka hadiah dan persembahan. Keluhuran Paulus dan Barnabas semakin terlihat setelah mereka menolak persembahan-persembahan itu. Mereka menegaskan bahwa mereka hanyalah manusia biasa.

Perjalanan Paulus dan Barnabas dilanjutkan ke Derbe dan kembali ke Antiokhia untuk kesekian kalinya. Di sana mereka mulai mengatur organisasi jemaat dengan menetapkan penatua-penatua jemaat. Mereka berpuasa dan berdoa sebelum menyerahkan penatua-penatua itu kepada Tuhan. Setelah perjalanan mereka ke beberapa tempat, Paulus dan Barnabas pergi ke Yerusalem untuk membawa persoalan yang terjadi di tengah umat yaitu soal pentingnya sunat bagi keselamatan (Kis 15:1-2). 
Di Yerusalem, Paulus dan Barnabas disambut oleh para rasul. Mereka menceritakan pertobatan orang-orang yang tadinya tidak mengenal Allah. ${ }^{48}$ Paulus dan Barnabas juga memberi kesaksian yang menguatkan kotbah Petrus (Kis 15:7-11) dan Yakobus (Kis 15:1321) tentang keselamatan Allah juga diperuntukkan kepada bangsa-bangsa lain. Kedua murid Tuhan ini menegaskan jangan sampai adat istiadat nenek moyang mereka menimbulkan kesulitan bagi mereka yang berasal dari bangsa-bangsa lain yang berbalik kepada Allah.

Hasil sidang di Yerusalem telah memutuskan sunat tidak diharuskan kepada bangsa-bangsa lain. Paulus dan Barnabas pun diutus kembali ke Antiokhia, kali ini ditemani oleh Yudas (yang disebut Barsabas) dan Silas. Mereka membawa keputusan yang dihasilkan di Yerusalem.

\section{Barnabas: Konflik Tentang Markus}

Antiokhia menjadi saksi kesuksesan karya kerasulan bagi Paulus dan Barnabas, tetapi di tempat ini juga kedua teman seperjalanan ini harus berkonflik dan akhirnya berpisah. Pada suatu ketika kedua sahabat karib ini berselisih paham dalam pelayanan. Dari Antiokhia, Paulus bermaksud melanjutkan misi mereka ke daerah-daerah lainnya. Perselisihan mereka dimulai dari niat Barnabas ingin membawa Yohanes yang disebut Markus untuk ikut serta dalam perjalanan mereka. Markus, anak muda yang pernah meninggalkan mereka dalam perjalanan mereka menuju Perga. Karena Markus adalah keponakan Barnabas, Fitzmyer beranggapan bahwa pilihan itu bukan berdasarkan profesionalitas Barnabas tetapi dari keinginan pribadinya sendiri. ${ }^{49}$

Niat Barnabas itu ditentang oleh Paulus. Dengan tegas Paulus berkata, bahwa tidak baik membawa serta orang yang telah meninggalan mereka di Pamfilia dan tidak mau turut bekerja bersama-sama dengan mereka. Perbedaan pendapat ini membuat Paulus dan Barnabas berpisah. Barnabas akhirnya membawa Markus ke Siprus, daerah asalnya. Sementara Paulus bersama Silas, rekan seperjalannya yang baru, berangkat mengelilingi Siria dan Kilikia dan mewartakan kasih karunia Allah di tempat-tempat itu.

Semenjak perpisahan itu, mulai Kisah Rasul 16, Paulus dan Barnabas seolah berjalan sendiri-sendiri. Kisah Barnabas dalam Kisah Para Rasul berakhir di Kis 15:39 dan tidak pernah disebut-sebut lagi. ${ }^{50}$ Nama Barnabas seolah hilang dari panggung cerita Kisah Para Rasul. Sebaliknya, Paulus, dengan kawan-kawannya yang baru, seperti Timotius, Silas dan Titus, semakin berkibar dan menjadi tokoh yang paling disorot dalam Kisah Para Rasul.

\section{KESIMPULAN}

Tidak diragukan lagi apa yang dilakukan oleh Barnabas kepada Paulus sangatlah besar dan penting. Meski telah berjasa besar, Barnabas tidak membesar-besarkan jasanya kepada Paulus ketika konflik di antara keduanya. Tidak ada dendam di antara mereka yang diceritakan dalam Kisah Para Rasul. Hal itu tentunya membuat Gereja Perdana terhindar dari perpecahan yang serius Dari figur Barnabas, si Anak Penghiburan, para murid Kristus bisa belajar banyak hal dalam melakukan pelayanan pastoral, termasuk ketika terjadi konflik dalam pelayanan.

Paper ini telah menelaah figur Barnabas yang bisa menjadi teladan orang beriman masa kini, di mana kita bisa belajar bagaimana seharusnya para murid-murid Kristus 
berelasi, berpastoral dan mempunyai relasi yang mendalam dengan Sang Kristus sendiri. Dari gambaran Barnabas di atas tidaklah mengherankan figur ini sangat menyentuh sisi pastoral dan spiritualitas Bapak Kardi-

\section{CATATAN AKHIR}

1 Penggunaan nama Saulus dan Paulus tidak ada kaitannya dengan pertobatan yang dialami oleh seorang tokoh yang kelak akan dikenal sebagai Paulus. Dua nama itu digunakan bersamaan, tidak seperti Abram menjadi Abraham atau Sarai menjadi Sara. Oleh penulis Kisah Para Rasul, nama Saulus digunakan untuk menegaskan latar belakang Yahudinya, di mana nama ini cukup banyak digunakan oleh orang Israel, seperti raja pertama bangsa Israel. Setelah Kos 13:9, penulis Kisah Rasul tidak lagi menggunakan nama Saulus tetapi Paulus. Sementara dalam konteks Yunani dan Romani, nama Paulus akan lebih sering digunakan.

2 Kis 13:4; bdk. Kis 13:2.

3 Lukas menulis Kisah Para Rasul dengan tujuan untuk menceritakan dinamika perkembangan Gereja Perdana, bagaimana Gereja berkembang dari Yerusalem sampai kepada bangsa-bangsa di mana kabar gembira Injil diwartakan. Untuk mengembangkan gagasan itu Lukas memilih beberapa tokoh yang dikembangkan seperti: Petrus, Yohanes, Yakobus (dari kelompok 12 rasul), termasuk juga Paulus, Barnabas dan beberapa tokoh lainnya. Justo González, Acts, The Gospel of the Spirit (NY: Orbis Books, 2001) 6-8.

4 Raymond Collins, "Representative Figures in the Fourth Gospel," Downside Review 94 (1976) 26-46, 118-32. Lihat juga Raymond Collins, These Things Have Been Written: Studies on the Fourth Gospel. Louvain Theological and Pastoral Monograph 2 (Louvain: Peeters Press) 1990.

5 Alan Culpepper, The Johannine School: An Evaluation of the Johannine School Hypothesis Based on an Investigation of the Nature of Ancient School, SBLDS 26 (MI: School Press, 1975) 145-148.

6 Alan Culpepper, Anatomy of the Fourth Gospel: A Study in Literary Design (PA: Fortress Press, 1983).

Lih Mrk 3:17.

8 Yoh 21:2 berbunyi: di pantai itu berkumpul Simon Petrus, Tomas yang disebut Didimus, Natanael dari Kana yang di Galilea, anak-anak Zebedeus dan dua orang murid yang lain.

9 Lih. Mat 10:3 // Mrk 3:18 // Luk 6:15 // Kis 1:13; Yoh 14:5; 20:25, 26, 27, 28.

10 Lih. Mat 16:16; Luk 5:8; Yoh 1:40; 6:8, 68; 13:6; 13:9; $21: 15$.

11 Lih. Mat 4:18; 10:2; Kis 10:5, 18, 32; 11:13.

12 Bdk. Luk 4:38; 5:3,4; Kis 10:18, 32; 11:13; 2 Ptr 1:1.

13 Lih Kis 1:14. Kisah Para Rasul hanya menyebut Petrus, nama panggilan yang diperoleh Simon dari Yesus.

$14 \quad$ Lih. Yoh 1:40; 6:8, 68; 13:6, 9,24, 36; 18:10, 15, 25; $20: 2,6 ; 21: 2,3,11,15$.

15 Lih. Mat 10:4; Mrk 3:18; Luk 6:15; Kis 1:13.

16 Lih. Mat 1:16, 18, 19, 20, 24, 25; 2:13, 14, 19, 21,22

17 Lih. Mat 27:57, 59; Mrk 15:43, 45, 46.

18 Kis $5: 1-11$.

19 Lih. C. W. Hedrik, "Paul Conversion: A Comparative analysis of the three reports in Act," JBL 100 (1981) 415-32. nal Ignatius Suharyo dalam karya pengembalaannya. Semoga kita semua, sahabat-sahabat Bapak Kardinal mampu menangkap dan meneladani Barnabas dalam karya dan hidup kita masing-masing.

$20 \quad$ Lih. Kis $11: 30 ; 12: 25 ; 13: 1,2,4,7,42,43,46,50,51 ; 14: 3$, $12,14,20,21 ; 15: 2,12,13,22,25,35,36$.

21 Damaskus atau disebut juga Damsyik adalah salah satu kota yang sangat berperan penting di daerah Syria. Rute Damaskus menjadi jalan yang menjadi pilihan utama bagi kereta kuda. Damaskus adalah kota tua, sudah ada sejak jaman Abraham (Kej 14:15; 15:2). Tujuan Saulus melalui jalan ini tidak lain adalah sinagoa-sinagoga yang ada di daerah itu. Lih. E. F. Bishop, "The Great North Road," TToday 4 (1947-48) 383-99.

22 Lih. Joseph Fitzmyer, The Acts of The Apostles, AB 31 (NY: Doubleday) 419. Sebetulnya sebelum Kisah Rasul menceritakan pertobatan Saulus dan pewartaan Injil kepada segala bangsa, sebetulnya pengajarang Kisah Rasul sudah sedikit mengangkat tema itu dengan menceritakan aktivitas Filipus dalam mewartakan Injil di banyak kampung di Samaria dan dalam perjalananya ke Gaza. Di Gaza Filipus mempertobatkan seorang sida-sida Etiopia. Tetapi yang mau ditekankan oleh Fitzmyer dalam pendapatnya adalah melalui Saulus, pewartaan kepada segala bangsa menyebar jauh lebih luas lagi, seperti di sekitar Asia Kecil bahkan ke Roma. Bdk. Kis 8:4-40.

23 Tarsus, kota asal Paulus (Kis 21:39) adalah sebuah kota tua yang luas, makmur dan terdidik di dataran Kilikia, yang berdekatan dengan rute perdagangan yang menyimpang dari Sungai Efrat ke Barat dan dari Antiokia ke Utara. W. M. Ramsay, "The Tarsian Citizenship of St. Paul," ExpTim 16 (1904-5) 18-21.

24 Ada sebuah permainan kata di ay. 15 ini. Saulus menganiaya orang-orang yang menyebut nama Tuhan (Kis 9:14). Namun kini, Saulus dipilihNya untuk memberitakan "nama" yang menjadi alasan ia menganiaya. Dan karena nama yang sama inilah hidup Saulus ke depan akan menderita karena nama itu (Kis 9:16). Lih. Legrand Baker, "How Much He Much Suffer for My Name, "ClerM 31 (1967) 109-11.

25 Penyebutan kata "saudara” seringkali digunakan dalam Kisah Para Rasul untuk menekankan sebuah relasi yang dekat di dalam komunitas murid-murid Tuhan. Kedekatan mereka diikat oleh pengalaman mereka akan Kristus yang bangkit. Secara tidak langsung sapaan Ananias kepada Saulus ini adalah sebuah penerimaan Saulus ke dalam komunitas Kristiani, minimal dari pribadi Ananias sendiri. Landasan Ananias adalah Saulus juga mengalami pengalaman yang sama, yaitu melihat Kristus yang bangkit. Bdk. Fitzmyer, The Acts of The Apostles, 222.

26 Kis 9:21 mengacu pada Kis 9:16.

27 Kisah ini mengingatkan kita pada kisah Perjanjian Lama, di mana para pengintai kota Yeriko yang dikirim oleh Yosua diselamatkan oleh seorang perempuan bernama Rahab di Yos 2:1-24. Rahab menurunkan para pengintai itu dengan tali melalui jendela, sebab rumah Rahab letaknya di tembok kota. Di 2Kor 11:33 Paulus menceritakan kisah ini dari sudut pandangnya sendiri. Bahkan kata Yunani untuk "keranjang" di sini, sama dengan kata yang digunakan dalam teks Septuaginta untuk Yos 2:15. Lih. Fitzmyer, The Acts of The Apostles, 436. 
JURNAL TEOLOGI, 08.02 (2019): 107-124

28 David Gill, “The Structure of Acts 9," Bib 55 (1974) 546-48

29 Lih. Francis Beare, "Note on Paul's visits to Jerusalem, " JBL 63 (1944): 407-9.

30 Dalam suratnya kepada jemaat di Galatia, Paulus menceritakan pengalaman perjumpaannya dengan para rasul di Yerusalem. Tetapi di situ Paulus mengatakan bahwa ia hanya berjumpa dengan Yakobus, saudara Tuhan Yesus. Yakobus yang dimaksud di sini bukan salah seorang dari kelompok dua belas rasul Tuhan. Bdk. Gal 1:19.

31 Fitzmyer menyebut beberapa ahli mempertanyakan subyek dari kata kerja "menceritakan" dalam Kis 9:27. Siapakah yang menceritakan pengalaman pertobatan Paulus dan aktivitasnya di Damsyik? Barnabas atau Paulus sendiri? Namun dari logika bahasa yang digunakan kita bisa mengatakan bahwa Barnabaslah yang melakukan, bukan Paulus. Fitzmyer, The Acts of The Apostles, 439.

32 Untuk pertama kalinya Kisah Para Rasul menceritakan bagaimana pada akhirnya para rasul "membawa keluar" warta Injil menembus batas wilayah Palestina. Antiokia, Fenisia dan Siprus adalah beberapa tempat yang menjadi tempat tinggal orang kristen Yahudi berbahasa Yunani, lebih tepatnya orang Yahudi di diaspora.

33 Lih. Carl Hermann Kraeling, "The Jewish Community at Antioch," JBL 51 (1932) 130-60. Lih. Juga B. P. Robinson, "Paul and Barnabas in Cyprus," Scripture Bulletin 26 (1996) 69-72.

34 Dengan kemunculan nama Yerusalem dalam bagian ini, bisa diartikan bahwa Barnabas diutus oleh Gereja induk sebagaimana yang ditekankan oleh pengarang Kisah Para Rasul. Fitzmyer, The Acts of The Apostles, 477.

35 Raymond Brown, J. P. Meier, Antioch and Roma: New Testament Cradles of Catholic Christianity (NJ: Paulist, 1983) 11-15.

36 Kata pasif "disebut kristen" bisa juga diterjemahkan dalam bentuk middle dalam tata bahasa Yunani, menjadi "menyebut diri mereka sendiri sebagai orang kristen". Dengan kata lain di sinilah orang-orang Antiokhia, berkat bantuan Barnabas dan Saulus, mereka menemukan identitas mereka sendiri sebagai murid-murid Tuhan. Lih. E. J. Bickerman, "The Name of Christians," HTR 42 (1949) 109-24.

37 Pada tahun kesembilan masa pemerintahan Klaudius, tepatnya tahun 49M, terjadi pengusiran besar-besara orang Yahudi dari kota Roma. Lih. S. Safrai, "The Problem of the Expulsion of the Jews from Rome in the Time to Claudius," in Jewish People, editor Safrai dan Stern, 180-83. F. F. Bruce, New Testament History (London: Nelson 1969) 257-87.

$38 \quad$ Bdk. 11:30; Lih juga 12:25; 13:4, 7.

39 Pendapat ini muncul pertama kali dari seorang ahli Kitab Suci bernama Ernst Käsemann. Lih. Ernst Käsemann, Commentary on Romans, editor dan penerjemah G. Bromiley, Grand Rapids: Wm. B. Eerdmans, 1980, 4. Gagasan Käsemann mengikuti apa yang sudah dikatakan oleh ahli lain yang bernama Wolf-Henning Ollrog yang meragukan bahwa di Kisah Rasul bab 11 Paulus adalah pemimpin jemaat di Antiokhia ketika ia datang ke Yerusalem. Lih. Wolf-Henning Ollrog, Paulus und seine Mitarbeiter: Untersuchungen zu Theorie und Praxis der paulinischen Mission, WMANT 50 (Neukirchen-Vluyn: Neukirchener Verlag, 1979) 17-18.
40 Gerd Lüdermann, Paul Apostle to the Gentiles, Studies in Chronology, trans. F. Stantley John (PA: Fortress Press, 1984) 6. Lüdermann berangkat dari Gal 2:1-2, di mana Paulus menceritakan keberangkatannya ke Yerusalem karena ia menerima wahyu. Di Yerusalem pun Paulus menceritakan sepak terjangnya mewartakan Injik kepada bangsa-bangsa lain. Artinya Paulus sudah menjalani misinya sendiri secara independen sebelum terjadi Sidang di Yerusalem.

41 Fitzmyer beranggapan bahwa perubahan urutan, di mana nama Paulus disebut di urutan pertama adalah sebuah usaha Kisah Para Rasul untuk menegaskan relasi Paulus dengan jemaat di Antiokhia, yang semakin lama semakin dekat. Paulus semakin berperan dalam jemaat di Antiokhia. Fitzmyer, The Acts of The Apostles, 495.

42 Tokoh Yohanes yang disebut juga Markus muncul pertama kali dalam Kis 12:12, yaitu ketika Petrus keluar dari penjara dan pergi ke rumah Maria yang disebut sebagai ibu dari Yohanes. Di rumah itu dikatakan banyak orang berkumpul dan berdoa. Tokoh ini juga muncul dalam 12:12; 13:5,13; 15:37,39; 2Tim 4:11; 1 Ptr5:13; Fil 24 dan Kol 4:10. Di surat kepada jemaat di Kolose itulah disebut Markus adalah keponakan dari Barnabas. B. T. Holmes, "Luke's Description of John Mark," JBL 54 (1935) 63-72. Beberapa ahli berasumsi bahwa Markus inilah penulis Injil Markus. Lih. Juga C. C. Black. "The Presentation of John Mark in the Acts of the Apostles," PRS 20 (1993) 235-54.

43 Barnabas dan Saulus mendapat perutusan mereka dari Roh Kudus. Hal ini cocok dengan gambaran yang kita temukan dalam Kis 11:23 bahwa Barnabas adalah pribadi yang penuh dengan Roh Kudus. Perutusan dari Roh Kudus memainkan peran penting karena Kisah Rasul mau menekankan peran Roh Kudus dalam karya dan perkembangan kabar gembira ke seluruh bangsa. Lih. Fitzmyer, The Acts of The Apostles, 495.

44 Beberapa ahli berpendapat bahwa pertobatan Sergius Paulus menginspirasi Saulus untuk mengganti namanya menjadi Paulus, nama yang sama dengan sang gubernur. Misalnya Conzelmann dan Ramsay. Namun fakta itu kiranya lebih menjadi sebuah kebetulan, dan tidak didukung oleh fakta sejarah. Lih. H. D. Saffrey, "Sergius Paulus," DBSup 12 (1993) 693-99.

45 Kemungkinan Markus menghindari perjalanan jauh yang akan ditempuh bersama Paulus, yaitu pergi dari Perga ke Pisidia, yang jaraknya kurang lebih $160 \mathrm{~km}$. Kemungkinan anak muda ini ke Yerusalem dan pulang ke rumah ibunya di sana. Bdk. Fitzmyer, The Acts of The Apostles, 509.

46 Bdk. Fitzmyer, The Acts of The Apostles, 494-495.

47 Bdk. 14:21; 15:2,22,35.

48 Lüdemann beranggapan bahwa kala itu Paulus menceritakan perjuangannya sebagai pewarta kabar suka Injil kepada bangsa-bangsa lain bahkan sebelum dia membantu Paulus di Antiokhia. Lih. Gerd Lüdermann, Paul Apostle to the Gentiles , 6.

49 Bdk. Fitzmyer, The Acts of The Apostles, 572. Fitzmyer mengatakan pengarang Kisah Rasul tidak menjelaskan lebih lanjut masalah utama yang menjadi konflik Barnabas dan Paulus ini.

50 Selain di Kisah Para Rasul, nama Barnabas muncul juga dalam surat-surat Paulus, ketika Paulus menceritakan perjalanannya, seperti dalam 1 Kor 9:6; Gal 2:1, 9. 


\section{DAFTAR RUJUKAN}

Beare, F. W., "Note on Paul's visits to Jerusalem, “JBL 63 (1944) 407-9.

Bickerman, E. J., "The Name of Christians," HTR 42 (1949) 109-24.

Bishop, E. F., "The Great North Road," TToday 4 (1947-48) 383-99.

Black, C. C., "The Presentation of John Mark in the Acts of the Apostles," PRS 20 (1993) 235-54.

Brown, R. E., J. P. Meier, Antioch and Roma: New Testament Cradles of Catholic Christianity (NJ: Paulist, 1983).

Bruce, F. F., New Testament History (London: Nelson), 1969.

Collins, R. F., "Representative Figures in the Fourth Gospel," Downside Review 94 (1976) 26-46.

, These Things Have Been Written: Studies on the Fourth Gospel. Louvain Theological and Pastoral Monograph 2 (Louvain: Peeters Press, 1990).

Culpepper, R. A., The Johannine School: An Evaluation of the Johannine School Hypothesis Based on an Investigation of the Nature of Ancient School, SBLDS 26 (MT: School Press, 1975).

, Anatomy of the Fourth Gospel: A Study in Literary Design (PA: Fortress Press, 1983).

Fitzmyer, J., The Acts of The Apostles, AB 31 (NY: Doubleday, 1998).

Gill, David, "The Structure of Acts 9," Bib 55 (1974) 546-48.
González, Justo L., Acts, The Gospel of the Spirit (NY: Orbis Books, 2001).

Hedrik C. W., "Paul Conversion: A Comparative analysis of the three reports in Act," JBL 100 (1981) 415-32.

Holmes, B. T., "Luke's Description of John Mark," JBL 54 (1935) 63-72.

Käsemann., E., Commentary on Romans, editor dan penerjemah G. Bromiley (MI: Grand Rapids, 1980).

Kraeling, C. H., "The Jewish Community at Antioch," JBL 51 (1932) 130-60.

Legrand, L., "How Much He Much Suffer for My Name, "ClerM 31 (1967) 109-11.

Lüdermann, G., Paul Apostle to the Gentiles, Studies in Chronology, penerjemah F. Stantley John dari buku yang berjudul Paulus, der Heidenapostel, vol I: Studien zur Chronologie (PA: Fortress Press, 1984).

Ollrog, Wolf-Henning, Paulus und seine Mitarbeiter: Untersuchungen zu Theorie und Praxis der paulinischen Mission, WMANT 50 (Neukirchen-Vluyn: Neukirchener Verlag, 1979).

Ramsay, W. M., "The Tarsian Citizenship of St. Paul," ExpTim 16 (1904-5) 18-21.

Robinson, B. P., "Paul and Barnabas in Cyprus," Scripture Bulletin 26 (1996) 69-72.

Saffrey, H. D., "Sergius Paulus," DBSup 12 (1993) 693-99. 
